\title{
VARIASI JUMLAH ELEKTRODA DAN BESAR TEGANGAN DALAM MENURUNKAN KANDUNGAN COD DAN TSS LIMBAH CAIR TEKSTIL DENGAN METODE ELEKTROKOAGULASI
}

\author{
Achmad Chusnun Ni'am ${ }^{1}$, Jenny Caroline ${ }^{1}$, M. Haris Afandi ${ }^{1}$ \\ Jurusan Teknik Lingkungan, Institut Teknologi Adhi Tama Surabaya, \\ Jl. Arief Rahman Hakim No. 100 Surabaya \\ Email: ach.niam@itats.ac.id ${ }^{1}$
}

\begin{abstract}
The quality of environment especially the water bodies need to be improved on the pollution load of the household wastewater, which in general still does not have a liquid waste treatment plant. Electrocoagulation used in this research because of the simple and efficient method. The aim of study to know the ability of electrocoagulation method for reducing the concentration of COD and TSS in the wastewater from household textile industry. The sample was taken from the residual wastewater of textile dye (sarung) with a liquid waste requirement of 36 liters. The data for the analysis is the initial and final parameters data were COD and TSS. The electrodes were used aluminum $(\mathrm{Al})$ as an anode and iron $(\mathrm{Fe})$ as a cathode. The research variations were used the number of electrodes and the voltage. The results showed that the treatment of 4 electrodes with 12 volt voltage could reduce the COD concentration up to $76 \%$ and TSS up to $85 \%$ in household wastewater of household textile industry.
\end{abstract}

Keywords: COD, electrocoagulation, liquid waste, TSS

\begin{abstract}
Abstrak
Kualitas lingkungan khusunya badan air perlu untuk diperbaiki terhadap beban pencemaran limbah cair industri tekstil skala rumah tangga, yang secara umum masih belum memiliki instalasi pengolahan limbah cair. Metode elektrokoagulasi digunakan dalam penelitian ini dikarenakan sederhana dan efisien. Tujuan dari penelitian ini adalah mengetahui kemampuan metode elektrokoagulasi dalam mennurunkan konsentrasi COD dan TSS pada limbah cair dari industri tekstil skala rumah tangg.. Sampel penelitian diambil dari air limbah sisa pewarnaan tekstil (sarung) dengan kebutuhan limbah cair sebanyak 36 liter. Data untuk analisis adalah data parameter awal dan akhir yaitu COD dan TSS. Elektroda yang digunakan adalah aluminium (Al) sebagai anoda dan besi (Fe) sebagai katoda. Variasi penelitian yang digunakan adalah jumlah elektroda dan besar tegangan. Hasil penelitian menunjukkan bahwa perlakuan pada jumlah 4 elektroda dengan tegangan 12 volt, mampu menurunkan konsentrasi COD hingga 76\% dan TSS hingga 85\% dalam limbah cair industri tekstil skala rumah tangga.
\end{abstract}

Kata kunci: COD, elektrokoagulasi, limbah cair, TSS

\section{PENDAHULUAN}

Metode pengolahan secara fisika dan kimia pada umumnya digunakan dalam teknologi instalasi pengolahan limbah cair tekstil. Pengolahan dengan kedua metode tersebut memerlukan biaya operasional yang tinggi, teknisi, dan lahan yang luas. Oleh karena itu, diperlukan teknologi pengolahan limbah yang tepat guna dan ramah lingkungan. Metode elektrokoagulasi merupakan salah satu metode yang dapat digunakan dalam mengolah limbah cair (titik). Metode ini dapat menyisihkan partikel tersuspensi, logam-logam berat, kekeruhan dan warna. Elektrokoagulasi menggunakan sumber arus langsung dari dua elektroda 
yang dimasukkan ke dalam air limbah (Elabbas et al., 2016).

Penelitian Yulianto (2009) menunjukkan bahwa metode elektrokoagulasi telah digunakan untuk menurunkan limbah cair industri batik. Penelitian tersebut menggunakan pasangan elektroda alumunium (Al) sebagai anoda dan besi (Fe) sebagai katoda dengan menggunakan perbedaan kuat arus dan perbedaan waktu yang terbukti dapat menurunkan konsentraasi COD sampai 30\%, untuk warna penurunan maksimum sebesar 64\%. Penurunan TSS dan minyak lemak dengan persentase tertinggi sebesar $77 \%$ untuk TSS dan 88\% untuk minyak dan lemak.

Metode elektrokoagulasi yang dilakukan dalam penelitian kali ini menggunakan jumlah variasi pasangan elektroda aluminium sebagai anoda dan besi sebagai katoda. Tegangan yang digunakan sebesar 4 dan 12 volt dengan lama waktu kontak selama 15 menit, 45 menit, 75 menit dan 105 menit. Parameter yang akan diuji dalam penelitian adalah COD, dan TSS. Metode elektrokoagulasi digunakan dalam penelitian ini disebabkan ramah lingkungan, ekonomis dan tidak memerlukan tambahan bahan kimia. Metode elektrokoagulasi dalam peneltian digunakan untuk mengolah limbah cair dari tekstil (sarung) dalam skala rumah tangga di Gresik.

\section{METODE PENELITIAN}

Limbah cair yang digunakan merupakan air limbah sisa pewarnaan tekstil (sarung). Volume limbah cair yang digunakan sebanyak 36 liter. Parameter yang diukur adalah Chemical Oxygen Demand (COD) dan Total Suspended Solid (TSS). Reaktor penelitian terbuat dari kaca dengan panjang $45 \mathrm{~cm}$, lebar $20 \mathrm{~cm}$ dan tinggi $30 \mathrm{~cm}$. Elektroda yang terdiri atas alumunium sebagai anoda dan besi sebagai katoda. Dimensi plat elektroda dengan panjang $10 \mathrm{~cm}$, lebar $15 \mathrm{~cm}$ dan tebal plat $1 \mathrm{~mm}$. Gambar 1. merupakan gambar reaktor penelitian.

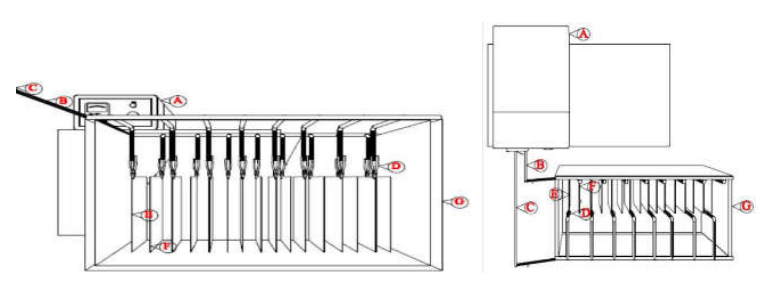

Gambar 1. Reaktor penelitian (a) tampak samping dan (b) tampak atas

Variasi yang digunakan dalam penelitian elektrolisis antara lain jumlah elektroda, tegangan, dan waktu kontak. Rincian variasi penelitian dapat dilihat pada tabel 1 .

Tabel 1. Variasi penelitian

\begin{tabular}{|c|c|c|}
\hline Jumlah elektroda & Tegangan (v) & Waktu (menit) \\
\hline \multirow{2}{*}{2} & 4 & \multirow{3}{*}{15,45, dan 75} \\
\cline { 2 - 2 } & 8 & \\
\cline { 2 - 2 } & 12 & \\
\hline
\end{tabular}

(Sumber: Data penelitian, 2016).

\section{HASIL DAN PEMBAHASAN}

Limbah cair berasal dari sisa pewarnaan sarung. Limbah ini dihasilkan dari industri skala rumah tangga. Berdasarkan uji sample limbah cair pewarnaan sarung diperoleh hasil analisis dari beberapa paramater yang disajikan pada Tabel 2 .

Tabel 2. Karakteristik awal limbah cair pewarnaan sarung

\begin{tabular}{clll}
\hline No & Parameter & Satuan & Nilai \\
\hline 1 & COD & $\mathrm{mg} / \mathrm{L}$ & 352,3 \\
\hline 2 & TSS & $\mathrm{mg} / \mathrm{L}$ & 137 \\
\hline 3 & BOD & $\mathrm{mg} / \mathrm{L}$ & 97,3 \\
\hline 4 & $\mathrm{pH}$ & & 7,31 \\
\hline 5. & Suhu & celcius & 29 \\
\hline
\end{tabular}

(Sumber: Hasil analisis, 2016).

Merujuk dari Peraturan Gubernur Jawa Timur No. 72 Tahun 2013 tentang baku mutu air limbah bagi industri dan/atau kegiatan usaha lainnya, karakteristik limbah cair yang digunakan dalam penelitian melebihi baku mutu untuk parameter COD, TSS dan BOD. 


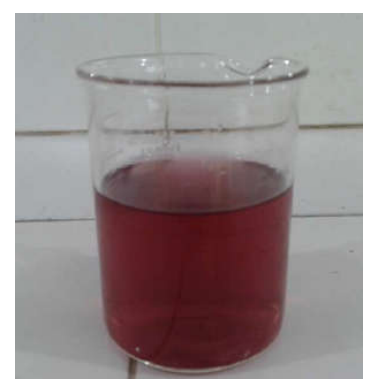

Gambar 2. Limbah cair tekstil (Dokumentasi Pribadi, 2016)

Penelitian dilakukan di laboratorium secara batch. Alat elektrokoagulasi terbuat dari dua komponen, yaitu reaktor elektrokoagulasi dan plat elektroda. reaktor elektrokoagulasi dibuat dengan dimensi $45 \mathrm{~cm} \times 20 \mathrm{~cm} \times 0,5 \mathrm{~cm}$. Plat elektroda terdiri dari alumunium dan stainless steel dengan dimensi $10 \mathrm{~cm} \mathrm{x} 15 \mathrm{~cm} \times 1 \mathrm{~mm}$. Parameter yang diuji dalam penelitian ini adalah suhu, $\mathrm{pH}$, COD dan TSS.

\section{Penurunan kandungan COD pada limbah cair tekstil}
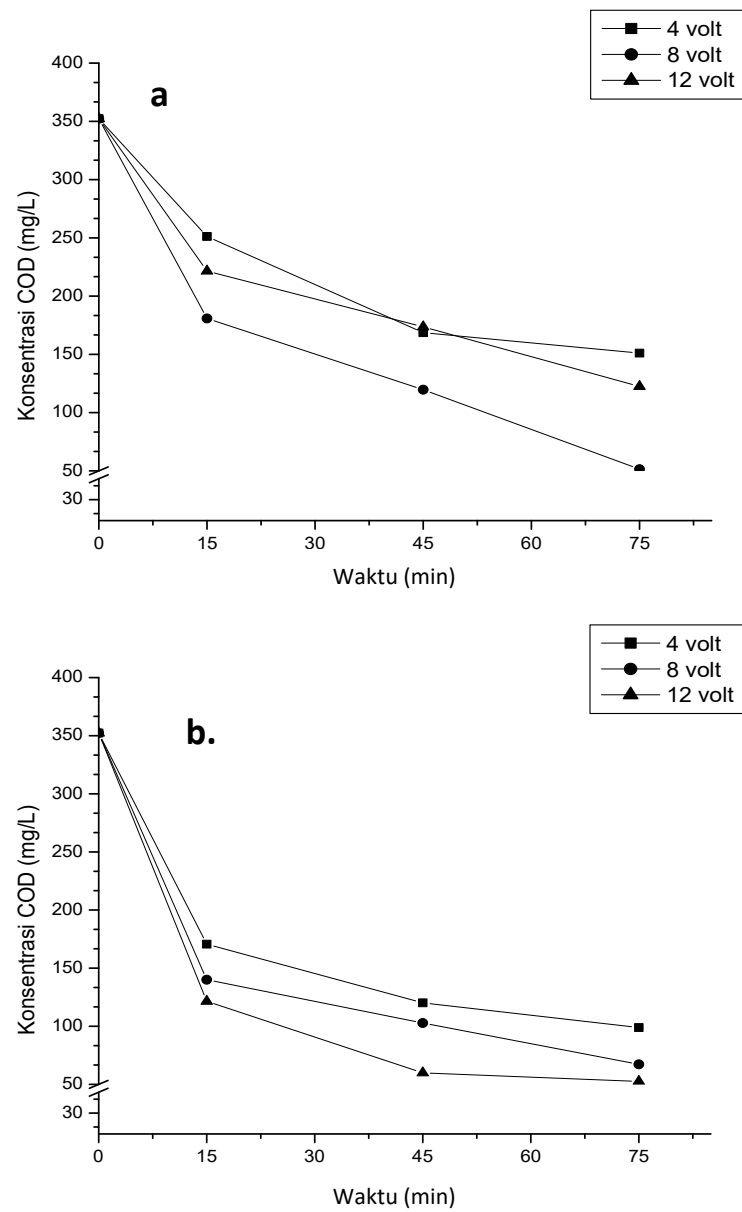

Gambar 3. Grafik penurunan konsentrasi COD limbah cair (a) jumlah elektroda 2 (b) jumlah elektroda 4

p-ISSN: 2460-8815, e-ISSN: 2549-1652
Pengukuran Chemical Oxygen Demand (COD) merupakan salah satu parameter untuk melihat derajat pencemaran yang telah diterima oleh air limbah. Pengukuran COD dimaksudkan untuk mengetahui besarnya kadar kebutuhan oksigen yang dibutuhkan untuk mengoksidasi zat organik secara kimia

Berdasarkan pada gambar 3 menunjukkan bahwa terjadi penurunan konsentrasi COD pada semua perlakukan. Penurunan konsentrasi terbesar, terjadi pada jumlah elektroda 4 buah dengan tegangan 12 volt selama 75 menit yaitu $51,5 \mathrm{mg} / \mathrm{L}$ dari konsentrasi awal 352,3 mg/L. Sedangkan, efisiensi penurunan konsentrasi COD terjadi secara fluktuatif. Berdasarkan penelitian ini menunjukkan bahwa semakin banyak jumlah elektroda yang digunakan, efektifitas penurunan konsentrasi COD menjadi semakin besar. Efisiensi penurunan konsentrasi terjadi pada perlakukan tegangan 12 volt dengan jumlah elektroda 4 sebesar $76 \%$ pada waktu operasi 45 menit (Gambar 4). menit.

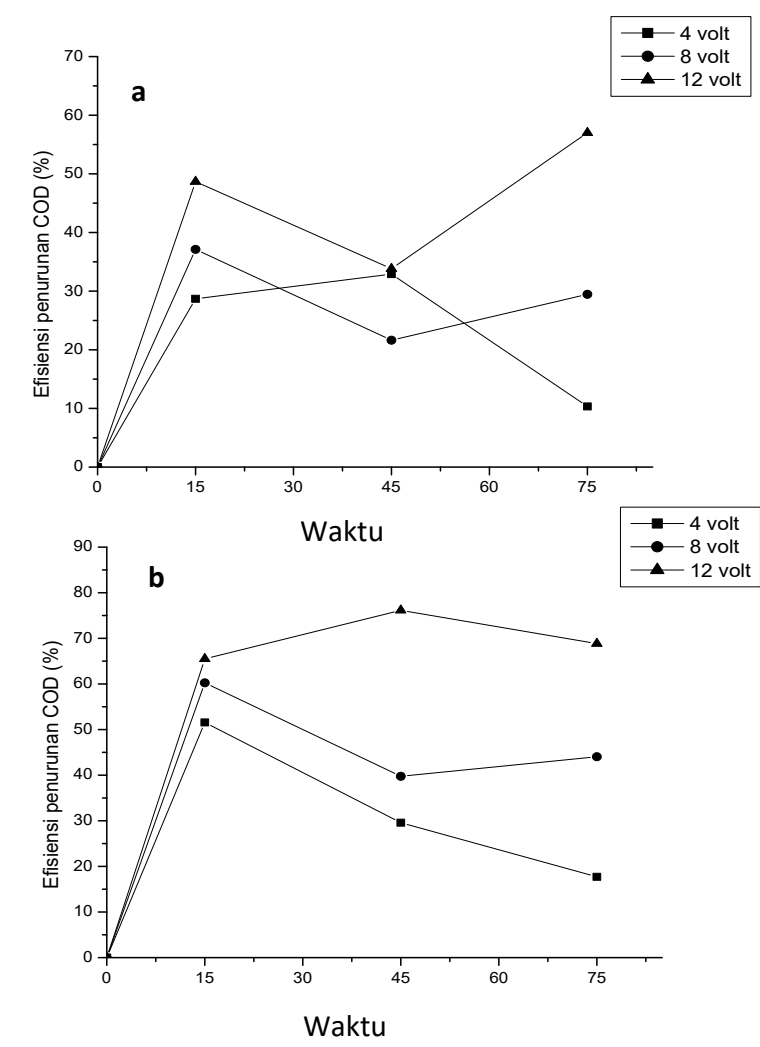

Gambar 4. Grafik efisiensi penurunan konsentrasi COD limbah cair (a) jumlah elektroda 2 (b) jumlah elektroda 4

Penelitian yang dilakukan oleh Naje et al., (2015) menyebutkan bahwa efisiensi 
removal COD sebesar $61 \%$ pada limbah tekstil dengan elektroda aluminium selama waktu 90 menit serta beda potensial listrik 0,6 ampere.Kisaran $\mathrm{pH}$ pada limbah cair berada di nilai 7-8 pada semua perlaukan Kenaikan nilai pH terjadi pada seluruh perlakuan sejalan dengan bertambahnya lama waktu perlakuan. Ketika lama waktu berlangsung hingga 15 menit, $\mathrm{pH}$ menunjukkan nilai 7. Nilai $\mathrm{pH}$ naik menjadi 8 setelah melewati waktu 15 menit hingga 75 Menurut penelitian Ni'am et al. (2007) melaporkan bahwa peningkatan nilai $\mathrm{pH}$ yang terjadi disebabkan karena pada proses elektrokoagulasi terjadi akumulasi $\mathrm{OH}$. Penelitian Nasution (2012) dalam Yolanda (2015) menyebutkan katoda pada proses elektrokoagulasi menghasilkan ion $\mathrm{OH}$ - yang akan menaikkan nilai $\mathrm{pH}$. Nilai $\mathrm{pH}$ larutan juga mempengaruhi mempengaruhi jumlah ion ion dalam larutan pada larutan dan kelarutan dari produk yang dibentuk. $\mathrm{pH}$ larutan mempengaruhi secara keseluruhan efisiensi dan efektifitas elektrokoagulasi.

Berdasarkan pada gambar 4 efisiensi penurunan konsentrasi COD terbesar yaitu di kisaran 65\%-76\% terjadi pada perlakukan jumlah 4 elektroda dengan tegangan 12 volt. Kisaran nilai pH 7-8 pada penelitian membantu dalam meningkatkan efisiensi penyisihan. Hal ini sesuai dengan penelitian yang dilakukan oleh Kobya et al. (2003) yang menyebutkan bahwa range nilai $6<\mathrm{pH}<9$ efektif dalam menurunkan COD pada limbah cair tekstil dengan proses elektrokoagulasi. Jumlah elektroda dan besar tegangan yang digunakan mempengaruhi proses elektrokoagulasi. Flok-flok yang mengikat kontaminan dihasilkan dari interaksi antara elektroda dan tegangan pada proses elektrokoagulasi.Semakin banyak flok yang dihasilkan makan proses elektrokoagulasi semakin baik. (Yulianto dkk., 2009).

\section{Penurunan kandungan TSS pada limbah cair tekstil}

Pengukuran TSS bertujuan untuk mengetahui padatan yang tidak terlarut pada air limbah. Padatan yang tidak terlarut tersebut, antara lain tanah liat, bahan-bahan organik tertentu, sel-sel mikroorganisme. Berdasarkan pada gambar 5 menunjukkan bahwa terjadi penurunan konsentrasi TSS pada semua perlakukan. Penurunan konsentrasi terbesar, terjadi pada jumlah elektroda 4 buah dengan tegangan 8 volt selama 75 menit dengan konsentrasi akhir 20,10 mg/L.

Penurunan TSS dikarenakan pertikelpartikel yang terkandung air limbah umumnya bermuatan negatif. Ion positif dan negatif yang dihasilkan oleh elektroda akan menstabilkan partikel-partikel yang terkandung didalam limbah (Yulianto, dkk. 2009). Pada elektroda anoda akan mengalami reaksi oksidasi terhadap anion (ion negatif) membentuk $\mathrm{Al}^{3+}$ dan mengikat $\mathrm{OH}-$ membentuk senyawa $\mathrm{Al}(\mathrm{OH})_{3}$ yang dapat mengikat polutan, sedangkan pada katoda akan menghasilkan gas hydrogen yang berfungsi untuk mengangkat flok yang terbentuk keatas permukaan, flok yang terbentuk semakin lama akan bertambah besar dan akhirnya mengendap ke dasar bak elektrokoagulasi (Novianti dan Agung, 2006).

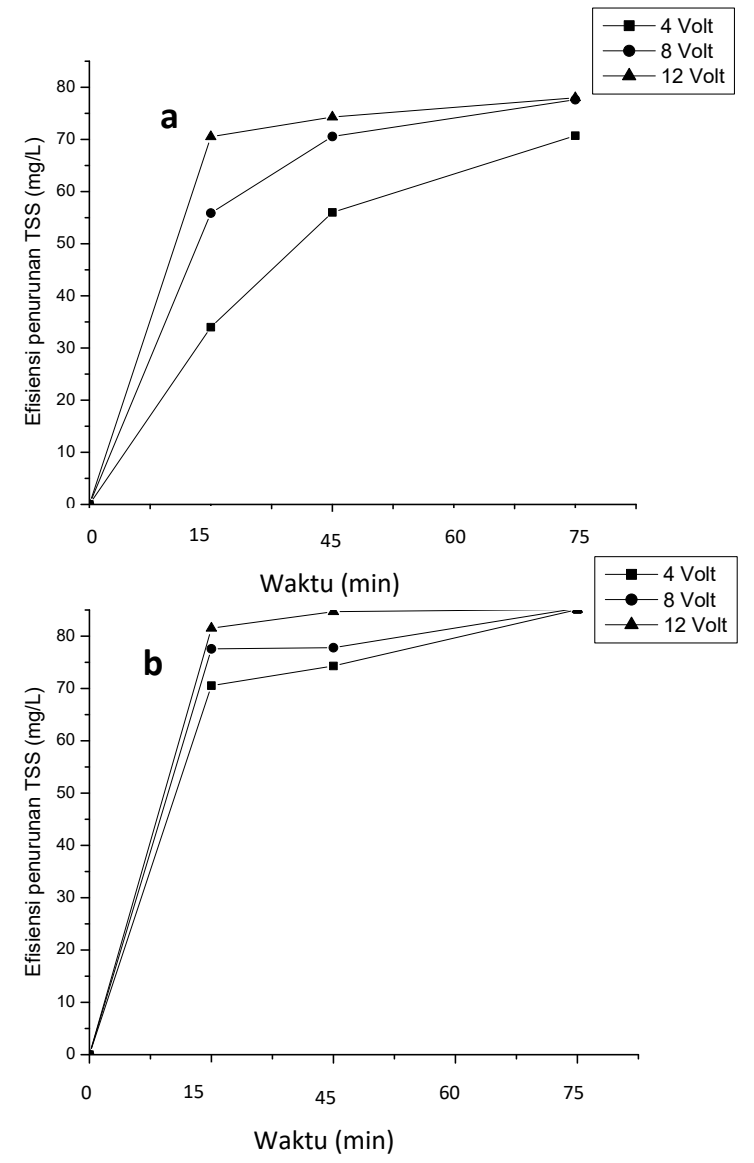

Gambar 5. Grafik penurunan konsentrasi TSS limbah cair (a) jumlah elektroda 2 (b) jumlah elektroda 4 
Berdasakan pada gambar 6 efisiensi penurunan konsentrasi TSS terbesar yaitu berada di kisaran $81-85 \%$ terjadi pada perlakukan jumlah 4 elektroda dengan tegangan 12 volt. Penelitian Hari dan Mining (2010) menyebutkan bahwa kadar TSS mengalami perubahan yang cukup signifikan dengan penurunan rata-rata sebesar $76,27 \%$ dan semakin menurun terhadap waktu pada proses elektrokoagulasi 30 menit mencapai $80 \%$.

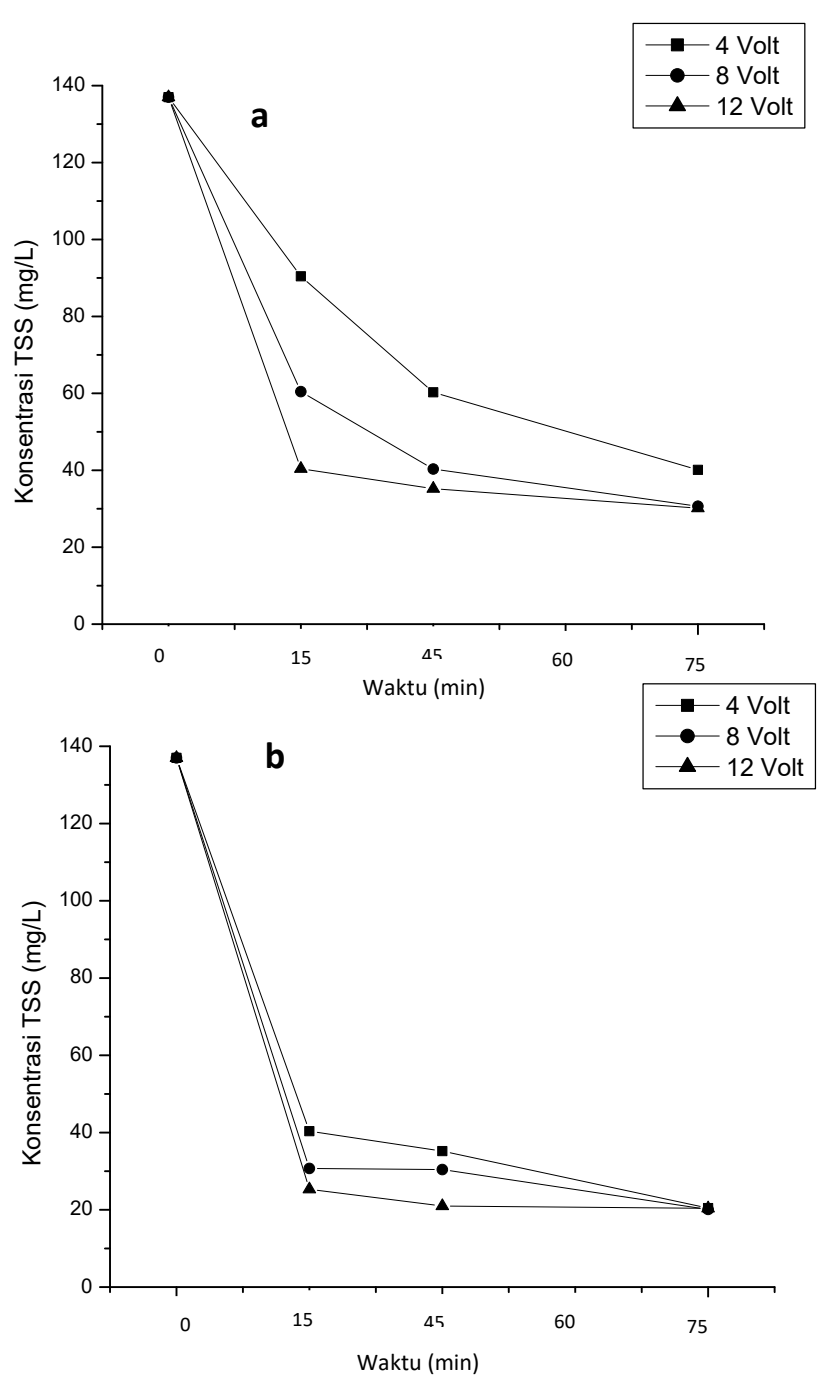

Gambar 6. Grafik efisiensi penurunan konsentrasi COD limbah cair (a) jumlah elektroda 2 (b) jumlah elektroda 4

\section{KESIMPULAN}

Kesimpulan yang didapatkan pada penelitian adalah metode elektrokoagulasi memiliki efisiensi dalam menurunkan konsentrasi COD hingga range 65\%-76\% pada perlakukan jumlah 4 elektroda dengan p-ISSN: 2460-8815, e-ISSN: 2549-1652 tegangan 12 volt dan efisiensi penurunan konsentrasi TSS terbesar didapatkan nilai 81$85 \%$ ada perlakukan jumlah 4 elektroda dengan tegangan 12 volt.

\section{DAFTAR PUSTAKA}

Elabbas, S., N. Ouazzani, L. Mandi, F. Berrekhis, M. Perdicakis, S. Pontviannee, M-N. Pons, F. Lapicquee, JP Leclerc. 2016. Treatment of highly concentrated tannery wastewater using electrocoagulation: Influence of the quality of aluminium used for the electrode. Journal of Hazardous Materials 319. 69-77

Hari, Bambang dan Mining H. 2010. Pengolahan Limbah Cair Tekstil Menggunakan Proses Elektrokoagulasi dengan Sel Al - Al. Prosiding Seminar Nasional Teknik Kimia "Kejuangan". Universitas Jendral Achmad Yani.

Kobya M., Orhan T.C., Mahmut. B. 2003. Treatment of Textile Wastewaters by Electrocoagulation Using Iron and Aluminum Electrodes. Journal of Hazardous Materials. Vol. 100. 163-178

Naje, A.S, Shreeshivadasan C., Zuriati Z., Saad A.A. 2015. Treatment Performance of Textile Wastewater Using Electrocoagulation (EC) Process under Combined Electrical Connection of Electrodes. Int. J. Electrochem. Sci., 10. $5924-5941$

Peraturan Gubernur Jawa Timur No. 72 Tahun 2013 tentang baku mutu air limbah bagi industri dan/atau kegiatan usaha lainnya

Niam, M.F., Othman F., Sohaili J. Dan Fauzia Z. 2007. Removal of COD and Turbididty to Improve Wastewater Quality using Electrocoagulation Technique. The Malaysian Journal of Analytical Science, 11(1):198-205

Novianti, D.L dan Agung T. 2006. Penurunan TSS dan Warna Limbah Industri Batik Secara Elektro Koagulasi. Jurnal Ilmiah Teknik Lingkungan. Vol.6 no.1

Yolanda G.M. 2015. Pengolahan Limbah Cair Laboratorium dengan Proses 
Elektrokoagulasi. Skripsi. Departemen Teknologi Industri Pertanian. Fakultas Teknologi Pertanian Bogor.

Yulianto, A., Luqman H., Indah P., Vidya Ayu P. 2009. Pengolahan Limbah Cair Industri Batik Pada Skala Laboratorium dengan Menggunakan Metode Elektrokoagulasi. Jurnal Teknologi Lingkungan. Vol 5, No. 